\title{
Ilan Alon and John R. McIntyre (eds), Globalization of Chinese Enterprises
}

Basingstoke, Palgrave MacMillian, 2008, 240 pp.

\section{Xavier Richet}

\section{OpenEdition}

\section{Journals}

Electronic version

URL: http://journals.openedition.org/chinaperspectives/4760

DOI: $10.4000 /$ chinaperspectives. 4760

ISSN: 1996-4617

\section{Publisher}

Centre d'étude français sur la Chine contemporaine

Printed version

Date of publication: 1 December 2008

Number of pages: 114-116

ISSN: 2070-3449

\section{Electronic reference}

Xavier Richet, « llan Alon and John R. McIntyre (eds), Globalization of Chinese Enterprises », China Perspectives [Online], 2008/4 | 2008, Online since 01 December 2008, connection on 24 September 2020. URL : http://journals.openedition.org/chinaperspectives/4760 ; DOI : https://doi.org/10.4000/ chinaperspectives.4760

This text was automatically generated on 24 September 2020 .

(c) All rights reserved 


\section{Ilan Alon and John R. McIntyre (eds), Globalization of Chinese Enterprises}

Basingstoke, Palgrave MacMillian, 2008, 240 pp.

\section{Xavier Richet}

1 This book is one of the first academic contributions analysing the factors pushing Chinese firms to internationalise their activities. ${ }^{1}$ The authors define and assess the factors that compel Chinese firms to go global, including internal ones, such as the acquisition of managerial, organisational, and technological skills, and external ones relations with central and provincial governments, the degree of competition, competitive advantage, and the role of institutions.

2 The work brings together 15 contributions grouped into four sections. The first section analyses the corporate capacity and the dynamics of China's external investments; the second focuses on institutional aspects of the firms' globalisation; the third examines this process through the experience of companies in Asia; and the last presents case studies of specific strategies followed by Chinese firms.

3 The book's contributors are mainly scholars from (or working in) the United States or China, and most are specialists in international business. The Chinese contributions are welcome for their ability to conceptualise internationalisation in terms of contemporary Chinese managerial thinking, often through the use of picturesque formulas ("dancing with wolves"). The contributors make their observations and analyses in line with a rigorous and homogeneous theoretical framework relevant to their discipline. This provides coherence but fails to prevent redundancies - several contributors start by repeating the conceptual framework of their studies. The analytical key, at once methodological and synthetic, is developed in Chapter 4 by Ilan Alon, Theodore Herbert, and Mark Munoz. They consider organisational aspects (infra microeconomic, internal to the firm) as well as strategic and institutional factors behind the success (and sometimes failure) of Chinese firms in the globalisation process. 
The Chinese economy is emerging in the framework of a far from complete institutional transition, as Shaomin Li underlines in the preface. The trajectory of China's internationalisation follows that of its Asian predecessors (Japan, South Korea), but in a different manner, notably in access the skills required to build competitive advantage. Japan and South Korea underwent a process of endogenisation of technology ("reverse engineering"). China's case has required technology import through the influx of foreign capital, and then a difficult assimilation and mastering of the technology ${ }^{2}$ before the firms, state-owned or private, proceed to carve up foreign markets.

Internationalisation of Chinese firms: Growth engines and modalities

6 Over the past few years, FDI (foreign direct investment) from China has been growing relentlessly, albeit at a rate far below that of investment inflows. The specialisation acquired over the past few decades through the entry of foreign capital has helped China become one of the world's main exporters of manufactured goods.

7 Why and how to internationalise Chinese firms at a time when the country is still heavily dependent on FDI for its growth and for technologies it has yet to master fully? These are two key questions the contributors seek to address.

8 The decision to internationalise, as highlighted in chapters 2 and 3, stems from many factors, including the need to acquire skills, the state's role, the degree of competition in the Chinese market, and finally (or above all) the need to acquire the raw materials for growth.

9 Acquisition of skills at the corporate level takes place in various ways: initiated through training linked to cooperation in joint-ventures with Western firms setting up shop in China, it then develops through an experience curve the Chinese call "yu lang gong wu" (dancing with wolves). It is during this phase that know-how is acquired through trial and error (mo zhe shi tou gui he), and skills develop within the firm and become tangible and intangible resources, according to Jay Barney's "resource-based theory of the firm." Once the firm has built this competitive advantage, another, riskier phase begins off-site, namely, learning through outward investment. According to Fangcheng Tang, Xu-dong Gao and Qiang Li (Chapter 3), a change occurs at this stage with the transition from a reactive strategy of "dancing with wolves" (the receiving and appropriating of technology and managerial know-how) to a proactive one (replication of acquired know-how) by putting it to use in the firms' externalisation (zou chu qu). This would appear to be a critical phase for the firm, and the authors note that the chances of success are not assured, as the learning process continues in a new institutional and cultural environment abroad.

10 At different stages of opening and modernisation, the state has played a dominant role through strategic choices that determined the localisation of new activities linked to cooperation with foreign firms. The state chose priority technologies and sectors, as well as the domestic enterprises with which foreign companies were allowed to cooperate. This facilitated a strategy of "technology exchange through the market" (shi chang huan ji shu) entailing a division of labour among partners: Western firms brought technology and took portions of the market, while the recipient Chinese firms focused on acquiring skills but made little money. Knowledge acquisition is difficult to achieve, because of obsolescence of technologies, the nature of national innovation systems, and intellectual property protection (especially after China's WTO accession). 
Western firms have often faced pressures to hand over advanced technologies before the signing of cooperation agreements. Many Chinese state firms adopted a "platform" approach (putting infrastructure, labour, and networks at their disposal, but few local technologies) in order to familiarise themselves with new technologies.

Cooperation with foreign firms and the resulting accumulation of know-how on the one hand, and the state's role in industrial policy, both specific (going global) and sectoral or regional, on the other, have prepared Chinese firms to conquer foreign markets. Another factor behind this movement has been the need to look abroad for assets that might strengthen the company and give it access to cutting edge technologies difficult to obtain at home either due to lack of local skills or because of the reluctance of foreign firms to transfer technologies. As stated many times in the book, while China's exports have been rising sharply, it is the foreign firms that have benefited most from exporting goods with a higher technology content.

Phases and modalities of internationalisation

13 The book's second part concentrates on the modalities of internationalisation by linking the institution, opening up, and specialisation of enterprises. One can't be certain that China's leadership had an a priori vision of corporate globalisation when economic reforms were launched, as a quotation from former President Jiang Zemin appears to show (p. 37). Moreover, China has witnessed many phases of internationalisation right from the outset of the construction of socialism. Xiahua Yang and Clyde Stoltenberg (Chapter 5) identify six phases. The first three are not too significant, as the internationalised firms played a supporting role in China's foreign engagements (cooperation, various supplies, major projects abroad). Other phases followed the launch of research and specialisation: a rise in the number and size of commercial firms, development of their internationalisation under state oversight (control of round trip investments), and finally, since the WTO accession, acceleration of foreign operations by both state and private enterprises, especially in sectors in which China seeks a competitive advantage. The government has also encouraged state firms that facilitate the development of raw material supply sources. WTO entry boosted domestic competition. Many Chinese firms found that internationalisation helped them reverse shrinking margins and expand profits. The proximity factor played a part: acquisition of necessary skills took place in nearby plants. Thus, Haier, a major global brand, trained its international cadres in the Philippines before they were sent further afield.

Apart from skill transfers, another important aspect of the success of internationalisation lies in a firm's specialisation. Those engaged in one activity or a given production segment (cheap cars) can turn out high volume, master technologies, and profit from economies of scale (capital, labour) that help create a competitive advantage for entering other markets, as exemplified by private automakers such as Geely. This has not proven to be the case with diversified groups that have benefited from state financing. Their management has proven difficult, with profitable businesses compensating for underperforming ones. The Chinese government is now more open to firms whose activities are more visible and focused and that have greater latitude to develop aggressive growth strategies.

15 Skills development at the regional level in northeastern China (Chapter 11) in electronics, or the accumulation and spread of know-how in a specific industry such as automobiles (Chapter 12), demonstrates the prerequisites for internationalisation. In 
electronics, the regional concentration of firms helped create positive externalities to local operators ensuing from cooperation and the presence of firms from other Asian countries. The same phenomenon is seen in the automobile industry, still highly fragmented (with more than 120 national-level assembly plants) and characterised by the presence of a number of foreign automakers in joint ventures and the entry of new nonstate competitors such as Geely and Chery that have begun making inroads abroad, especially in Asia and the Middle East.

Finally, can China draw inspiration from the experience of South Korea's companies, the Chaebols, or imitate Taiwanese inter-firm networking strategies (chapters 9 and 10)? These two organisational models have proven their worth but would need major institutional reform in order to be applied in China. The Chinese economy's rapid growth, the rise in domestic costs, and China's role as a regional powerhouse are changing regional economic relations and having an impact on economies such as that of Vietnam, which is trying to take advantage of transformations in the production systems and dynamism of firms in China (Chapter 8).

Through these diverse contributions, the book provides a better grasp of the dynamics unfolding at a critical phase of China's economic growth. The industrial model followed since the launch of economic reform has consisted of imitating the Asian model of export-led growth, while benefiting from the presence of foreign firms via FDI as a conduit for acquiring capital, technology, management, and markets. The heart of this strategy is the notion of appropriation to modernise the domestic productive apparatus through cooperation and dissemination. In some sectors, Chinese firms have begun internationalising and playing in the big league, aided by the acquired skills, degrees of competitiveness, technologies involved, and government assistance (with market access and financing). The analyses in the book depict the reality of this movement, which is changing the contours of Chinese and Asian production systems.

Under what conditions can firms become major long-term competitors? What obstacles block their global growth? There is no single answer, the book shows, while presenting analysis to better anticipate the prospects of the firms' internationalisation.

\section{NOTES}

1. On the internationalisation of firms from emerging countries, see the annual reports of the Boston Consulting Group: The New Global Challenger: How 100 Top Companies from Rapidly Developing Economies Are Changing the World (2007), p. 30, and The 2008 BCG 100: The New Global Challengers (2008), p. 13. See also Andrea Goldstein, Multinational Companies from Emerging Economies, Palgrave, 2008.

2. On this point, see Wang Wei and Jean-François Huchet (eds.), Chinese Firms in the Era of Globalisation, Beijing, China Development Press, 2008. 